\title{
Clinical Benefits of Switching from Original Infliximab to its Biosimilar (CT-P13) as a Potential TNF- $\alpha$ Inhibitor
}

\author{
Archana Kumari ${ }^{1}$, Deo Nandan Prasad ${ }^{2}$, Sahil Kumar ${ }^{3}$ and Rajesh K. Singh²* \\ ${ }^{1}$ Department of Pharmaceutical Chemistry, Rayat-Bahra Institute of Pharmacy, Dist. Hoshiarpur, Punjab, India; ${ }^{2}$ Department of Pharma- \\ ceutical Chemistry, Shivalik College of Pharmacy, Nangal, Dist. Rupnagar, Punjab, India; ${ }^{3}$ Department of Pharmacy, School of Medical \\ and Allied Sciences, G. D. Goenka University, Sohna, Dist. Gurugram, Haryana, India
}

\begin{abstract}
Tumor necrosis factor-alpha (TNF- $\alpha$ ) is implicated in the process of various autoimmune and inflammatory diseases through binding to its receptor, the tumor necrosis factor receptor. Nowadays, monoclonal anti-TNF- $\alpha$ antibody is used for the treatment of these diseases because it can neutralize TNF- $\alpha$ to block the relevant signaling responsible for the pathogenesis of these diseases. Currently, such antibody-based therapies have been demonstrated to be effective in controlling rheumatoid arthritis, psoriatic arthritis, ankylosing spondylitis, Crohn's disease and ulcerative colitis. Infliximab is the first monoclonal antibody for the treatment of rheumatoid arthritis and has been approved for the intervention of other autoimmune and inflammatory diseases in the clinic. Although infliximab is considered highly efficacious, more so than common medications such as methotrexate and calcipotriol, its potential disadvantages, including loss of response in some patients, drug-related adverse events and particularly high cost, have motivated chemists and researchers to shift towards its biosimilar, CT-P13. CT-P13 has a better tolerance and much less cost, attracting more attention. Here, we summarize the clinical findings of CT-P13 from clinical trials in various diseases.
\end{abstract}

\section{Introduction}

The proinflammatory cytokine, tumor necrosis factor (TNF- $\alpha)$ makes a great contribution to immune system regulation, being involved in cell growth and proliferation upon binding with its receptor. ${ }^{1,2}$ Improper TNF- $\alpha$ production has been seen in a variety of human diseases, including Alzheimer's disease, ${ }^{3}$ cancer,${ }^{4}$ major depression, ${ }^{5}$ psoriasis, ${ }^{6}$ and inflammatory bowel disease (IBD). ${ }^{7}$

Keywords: Infliximab; CT-P13; TNF- $\alpha$; Monoclonal antibody; Clinical study. Abbreviations: ACR, American College of Rheumatology; AUC, area under curve; $\mathrm{C} / \mathrm{EBP} \beta$, CCAAT-enhancer-binding proteins; CAV, average concentration; $\mathrm{CD}$, Crohn's disease; CI, confidence interval; Cmax, ss, maximum steady-state serum concentration; Cmin, minimum blood plasma concentration; CRP, C-reactive protein; CT-P13, infliximab biosimilar; DAS28, disease activity score; EMA, European Medicine Agency; FADD, Fas-associated protein with death domain; FDA, Food and Drug Administration; IBD, inflammatory bowel disease; IKK, inhibitor of kappa B kinase; JNK, c-Jun N-terminal kinases; MAPK, mitogen -activated protein kinase; MKK, MAP kinase kinases; MRT, mean residence time; NIK, NF- $\mathrm{BB}$-inducing kinase; PI3K, phosphoinositide 3-kinase; PK, pharmacokinetic; RIP, receptor-interacting protein; STAT, signal transducer and activator of transcription; TAB, ubiquitin binding proteins; TAK, TGF- $\beta$ activated kinase; Tmax, time-to-maximum; TNF, tumor necrosis factor; TNFR, tumor necrosis factor receptors; TRADD, TNF-receptor-associated death-domain protein; TRAF, TNF receptor associated factor; UC, ulcerative colitis. Received: February 22, 2020; Revised: March 20, 2020; Accepted: April 10, 2020

*Correspondence to: Rajesh Kumar Singh, Department of Pharmaceutical Chemistry, Shivalik College of Pharmacy, Nangal, Dist. Rupnagar, Punjab, India. Tel: +919417513730, Fax:+1887-221276, E-mail: rksingh244@gmail.com

How to cite this article: Kumari A, Prasad DN, Kumar S, Singh RK. Clinical Benefits of Switching from Original Infliximab to its Biosimilar (CT-P13) as a Potential TNF- $\alpha$ Inhibitor. J Explor Res Pharmacol 2020;5(2):9-17. doi: 10.14218/JERP.2020.00004.
TNF-alpha (TNF- $\alpha$ ) inhibitors can be widely used for all these disease conditions. TNF- $\alpha$ was declared, in 1975, as a circulating antitumorigenic cytokine produced from such immune cells as activated macrophages and lymphocytes. ${ }^{8,9}$ On binding with receptors, it controls the expression of inflammation and injury. It is a transmembrane protein with 212 amino acid sequence, existing in a homotrimer stable form that binds with two receptors, TNFR1 and TNFR2. ${ }^{10}$

TNF signaling controls immune cell activation via regulation of gene expression of chemokines, cytokines, and toxic molecules, including the reactive oxygen species, transcription factor nuclear factor-kappa $\mathrm{B}(\mathrm{NF}-\mathrm{kB})$ and mitogen-activated protein kinase (MAPK). ${ }^{11}$

Ligand binding induces the activation of TRAF $2 / 5$ and TRAF 2 through TNFR1 and TNFR2 in the membrane, respectively. Mainly, it controls three pathways through the TNFR1, inducing the proliferation of various kinases. ${ }^{12}$ Sequential NIK/IKK/NF- $\kappa B$ and TRADD/ FADD/caspase-8/10/caspase-3 are the central signaling chains for cell growth, proliferation and apoptosis. TAK1 is an ubiquitin-dependent kinase. ${ }^{13}$ Further, TAB2 and TAB3 recognize polyubiquitin chains and activate TAK1. TAK1 adaptor proteins, $\mathrm{TAB} 2$ and $\mathrm{TAB} 3$, link the signalosome to B-cell receptor-induced IKK activation. ${ }^{14,15}$ MKK3 and MKK6 are both involved in the activation of p38 kinase. Where, MKK3 and MKK4 selectively inhibit $\mathrm{p} 38 \delta$ and $\mathrm{p} 38 \gamma$ isoforms, respectively. The $\mathrm{p} 38 \alpha$ further activates CCAAT/enhancer-binding protein $\beta(\mathrm{C} / \mathrm{EBP} \beta)$ resulting in cancer-related consequences, i.e. protein translation, cell differentiation and cell growth. ${ }^{16}$ 


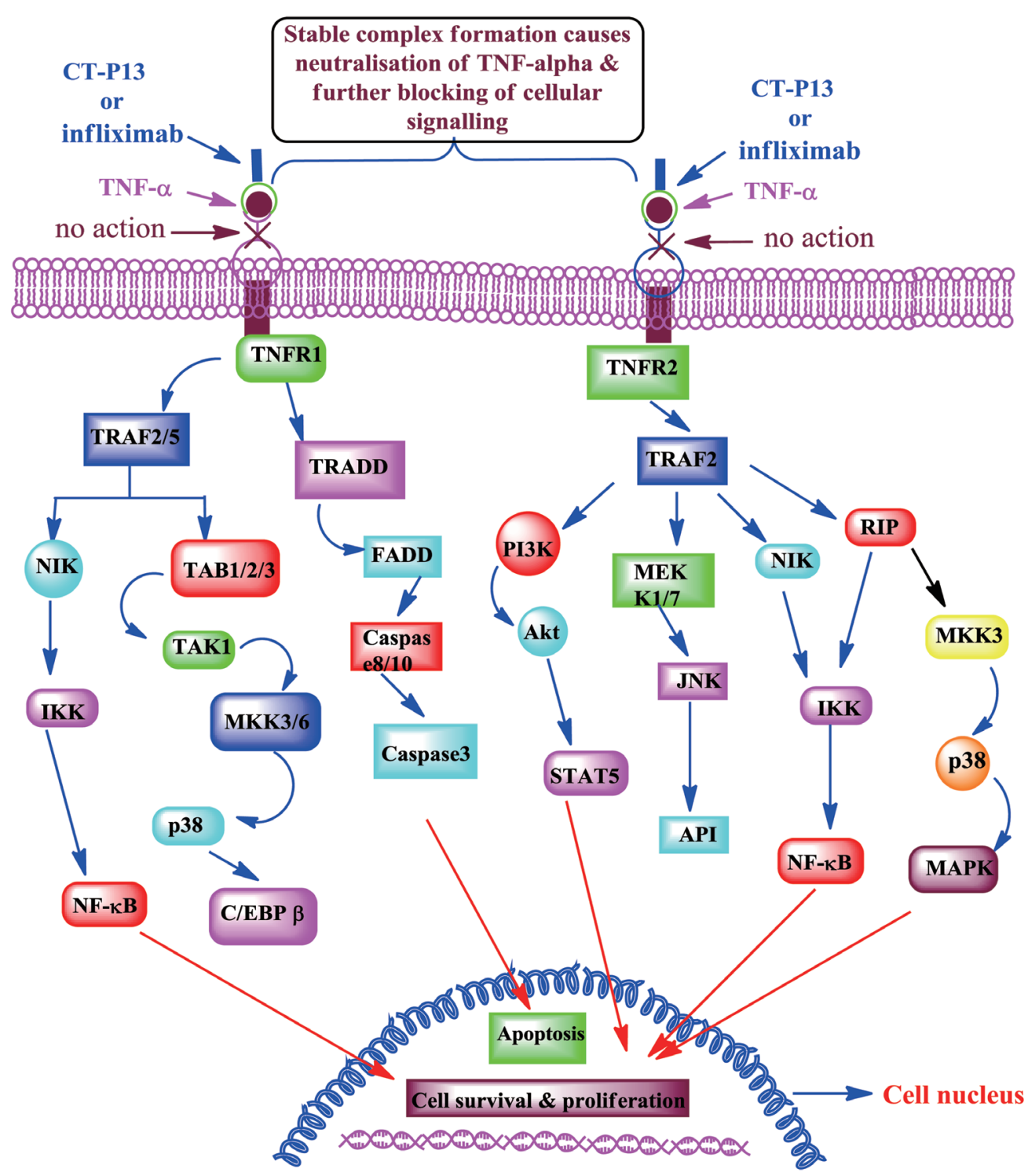

Fig. 1. Molecular mechanism of action of infliximab and infliximab biosimilar (CT-P13). Ligand binding of TNF- $\alpha$ with receptor TNFR1 and TNFR2 induces the activation of various cytokines and initiates cell signaling. Signaling through TNFR1 mainly follows various routes: one is, NIK/IKK/NF-KB and CCAATenhancer-binding proteins activation by MKK3/6 through TRAF2/5. Caspase-3 direct activation occurs via TNFR1 through TRADD/FADD proteins. TNFR2 induces the phosphorylation of kinases through TRAF2, involving the same pathway of NF-KB activation. MAPK activation occurs through MKK3, which is involved in cell survival and proliferation. TRAF2 activates PI3K/Akt/STAT5. Activator protein 1 is a transcription factor, regulating gene expression, involving TRAF2/MEKK1/7/JNK/AP1. Infliximab and its biosimilar (CT-P13) binds with TNF- $\alpha$ and inhibits this overall process of kinase proliferation and activation.

TNFR2 is also involved in signaling of some major pathways, such as that of TNFR1. STAT5 protein, involved in cytosolic signaling, is activated by TRAF2 through PI3K. NF-kB is another protein complex that is controlled by TRAF2 through both NIK and RIP. RIP is also involved in the phosphorylation of other major kinase, MAPK, through the MKK3/p38 chain. All these three pathways significantly control transcription of DNA, cytokine production, and cell survival. ${ }^{17}$ API is an activator of extracellular signal-regulated kinase. The signaling pathway is activated by MEK1/7/c-Jun N-terminal kinases (JNK). MKK4 and MKK7 phosphorylate JNK on tyrosine and threonine, respectively. Infliximab and its biosimilar CT-P13 neutralize TNF- $\alpha$ by forming a stable complex with TNF- $\alpha$, thereby inhibiting the binding of
TNF- $\alpha$ with its receptor. This results in blocking of the cell signaling pathway (Fig. 1). ${ }^{18}$

TNF- $\alpha$ inhibitors as therapeutic agents

TNF- $\alpha$ can be inhibited with monoclonal antibodies, such as infliximab (Remicade), ${ }^{19}$ adalimumab (Humira), ${ }^{20}$ certolizumab pegol (Cimzia), ${ }^{21}$ and golimumab (Simponi), ${ }^{22}$ or with a circulating receptor fusion protein, such as etanercept (Enbrel). ${ }^{23}$ Adalimumab is marketed with the name Humira and is the $150^{\text {th }}$ most prescribed drug in the United States. ${ }^{24}$ It is used for the treatment of rheumatoid arthritis, psoriatic arthritis, ankylosing spondylitis, Crohn's 
disease (CD), ulcerative colitis (UC), psoriasis, hidradenitis suppurativa, uveitis, and juvenile idiopathic arthritis. ${ }^{25,26}$ In 2014, the adalimumab biosimilar was introduced in India, which was less expensive than the original. Certolizumab pegol (CDP870, trade name Cimzia) is also used for the treatment of $\mathrm{CD},{ }^{27,28}$ rheumatoid arthritis, psoriatic arthritis, and ankylosing spondylitis. It is a fragment of a monoclonal antibody specific to TNF- $\alpha$ and manufactured by UCB (a multinational biopharmaceutical company). ${ }^{29,30}$ In 2008, Cimzia (certolizumab pegol) was approved by the US Federal Drug Administration (FDA). Cimzia biosimilar, with the product name PF688, is under clinical trial. ${ }^{31}$ Golimumab (CNTO $148)^{32}$ is another human monoclonal antibody, marketed under the brand name Simponi, used to treat rheumatoid arthritis, psoriatic arthritis, ankylosing spondylitis, and UC. A proposed biosimilar of golimumab, named as BAT 2506, is under Phase I clinical trial for the treatment of autoimmune disorders and is being developed by Bio-Thera Solutions. ${ }^{33}$

\section{Infliximab as a potential TNF- $\alpha$ inhibitor}

Infliximab (sold under the name Remicade) is a chimeric monoclonal antibody, having an approximate molecular weight of 149,100 Daltons. Infliximab was first approved by the US FDA on August 24, 1998, then approved by the European Medicine Agency (EMA) on August 13, 1999, Pharmaceuticals and Medicals Devices Agency of Japan on January 17, 2002, and China FDA on May 17, 2006. It was initially developed by Janssen (a member of Johnson \& Johnson), then co-marketed as Remicade ${ }^{\circledR}$ by Janssen, Merck \& Co and Mitsubishi Tanabe. It is used for the treatment of $\mathrm{CD}, \mathrm{UC}$, rheumatoid arthritis, ankylosing spondylitis, psoriasis, psoriatic arthritis, and Bechet's disease by inhibiting TNF- $\alpha .^{34}$

Infliximab is a TNF- $\alpha$ blocker that binds with high affinity to the soluble and transmembrane forms of TNF- $\alpha$ in order to neutralize it. It is indicated for the treatment of patients with $\mathrm{CD}, \mathrm{UC}$, rheumatoid arthritis, ankylosing spondylitis, psoriatic arthritis, plaque psoriasis, and Bechet's disease. The primary mechanism of TNF- $\alpha$ involves downstream signaling controlling various immune diseases. By forming a stable complex with both soluble and membrane forms of TNF- $\alpha$, it inhibits the binding of TNF- $\alpha$ with its receptor and thereby blocks the cell signaling pathway (Fig. 1). Infliximab increases apoptosis and cell cycle arrest in the T-cell line via reverse signaling. While using infliximab, some precautions are required to be taken because it may create some unwanted conditions, such as autoimmunity, malignancy, immunogenicity, and hypersensitivity conditions. ${ }^{35}$

\section{Infliximab biosimilar (CT-P13) as a potential substitute for in- fliximab}

Genetic engineering produces infliximab antibody by fusing the variable regions of a murine antibody $(25 \%)$ with the constant regions of a human antibody (75\%) at the hinge region. The crystal structure of infliximab can be determined by the data obtained from MolProbity score, and two domains (Fab with heavy and light chain and Fc with only heavy chain) are considered. In the heavy chain, amino acid residues Glu-1 to Thr-226 are found, and in the light chain amino acid residues Asp-1 to Cys-214 are found. $\mathrm{N}$-terminus linked with the heavy and light chain acts as the receptor binding site. ${ }^{36}$

The marketed price of infliximab monoclonal antibodies is quite high. According to a report from London in 2016, the annual cost of infliximab was around $£ 5,000-£ 10,000 .{ }^{37}$ In the UK, an estimated one person in 250 is suffering from IBD. ${ }^{38}$ To solve this problem, the biosimilar antibody concept was introduced, boasting equal potency, efficacy and safety but lower cost. ${ }^{39}$ Biosimilarsbiologics have high similarity but are price competitive with the originators, lowering medical costs.

All FDA-approved biosimilar undergo a rigorous evaluation to ensure that patients can rely on their efficacy, safety and quality. Development of these biosimilars involves a well-designed program and must include data demonstrating biosimilarity to the original drug in terms of safety, purity and potency. Data obtained from analytical studies, animal studies and clinical studies (pharmacokinetics and pharmacodynamics) of biosimilar are compared with the original drug and are taken into account while approving any biosimilar drug..$^{40}$ In 2015 , the US FDA began to approve biosimilars and up to July 2019 has granted a total of 16 antibody therapeutics. $^{41}$ Ranbaxy Laboratories Limited (Ranbaxy), Gurgaon launched India's first infliximab biosimilar at the Indian Rheumatology Association Conference in Chandigarh. ${ }^{42}$

After a consistent and methodical investigation, various countries declared the outcomes of their successful studies. The European Congress of Rheumatology 2019 presented positive outcomes of a subcutaneous formulation of CT-P13 (Remsima) by Celltrion Healthcare's (Celltrion). They also discussed the results collected from clinical trials phase I/III studies from June 2018 to August 2018 in their entirity. ${ }^{43}$ Celltrion, a South Korean biotechnology company, conducted the research of one year and reported the pharmacokinetics, efficacy and overall safety data of subcutaneous form of CT-P13 in rheumatoid arthritis. ${ }^{44}$

Financial gains with the implementation of a biosimilar concept were noticed from the economic budget standpoint and have drawn the attention of economists. In The Netherlands, the total cost saving is $€ 493$ million over 5 years for IBD, similar to that for the Dutch population. ${ }^{45}$ Central and Eastern Europe offer a $20-70 \%$ price discount on biosimilars to improve biological therapy. ${ }^{46} \mathrm{Con}$ sidering the cost, clinicians could switch to an infliximab biosimilar. As per the definition of the EMA, switching is the exchange of one medicine with another medicine with the same therapeutic intent. ${ }^{47}$ With the switching of infliximab to infliximab biosimilar (CT-P13), expenditure becomes half of the original. ${ }^{48}$ According to the World Health Organization, a biosimilar is defined as "a biotherapeutic product which is similar in terms of quality, safety and efficacy to an already licensed reference biotherapeutic product". 49

Switching from an original to a biosimilar involves both medical and non-medical motives. Reasons for medical switching are linked to patient health, safety, efficacy, side effects, or adherence. Through years of trials of various therapies, drugs are finalized with the least amount of side effects. On the other hand, non-medical switching is due to less cost or to increase the financial profits of companies. ${ }^{50}$ Many countries follow non-medical switching to maintain capital financial conditions. ${ }^{51}$

Result outcomes of various clinical studies on switching to infliximab biosimilar (CT-P13)

Infliximab biosimilar (CT-P13) was authorized by India and South Korea for the treatment of autoimmune disease in 2012.52 The EMA approved the biosimilar of infliximab (CT-P13) as well.53 Subsequently, CT-P13 was the first biosimilar monoclonal antibody to be approved in the US for IBD, in $2016 .{ }^{54}$ Various test studies have been conducted in many disease conditions and reported in the literature. The data produced during the trials related 
to switching from infliximab to the biosimilar CT-P13. To confirm efficacy and biosimilarity between CT-P13 and infliximab, various clinical efficacy studies have been conducted among the homogenous and susceptible population. ${ }^{55}$

A range of reports collected from various studies and trials conducted by researchers to prove the non-inferiority and tolerability of infliximab biosimilar CT-P13 is given below:

\section{Prospective role of CT-P13 in IBD}

IBD is a chronic inflammatory condition that mainly affects the digestive tract. $\mathrm{CD}$ and $\mathrm{UC}$ are two forms of IBD. Where, CD most commonly affects the small intestine (ileum) and colon, UC affects the colon and rectum. ${ }^{56}$ According to Centers for Disease Control and Prevention, about 3 million people have IBD in the US. ${ }^{57}$ This massive amount of disease condition can only be treated by switching to biosimilars featuring easy accessibility, low cost, and high tolerance. ${ }^{\mathbf{5 8}}$

Biosimilarity of infliximab and CT-P13, without any significant change in efficacy, was observed for CD by the European Crohn's Colitis Organisation in $2015 .{ }^{59}$ Research demonstrated that exchange of infliximab with CT-P13 is possible for CD and other inflammatory disorders. ${ }^{60}$ CT-P13 is well tolerated with the same dose as that of infliximab and without change in immunogenicity. ${ }^{61}$ Because of its good cost-saving strategy, it received marketing authorization and easy accessibility. ${ }^{62}$ In the real-life study, improved disease condition was observed with the use of CT-P13. Other studies have shown more effectiveness and tolerability in patients with UC. ${ }^{63}$ The Peruvian Social Security (known as EsSalud) reported biosimilarity between infliximab and CT-P13, and according to financial analysis determined it is a cost-effective decision. $^{64}$

In 2013, Park and colleagues ${ }^{65}$ reported a Phase 1, doubleblind, parallel-group study of 22 and 30 weeks on 250 patients administered with either CT-P13 $(n=125)$ or infliximab $(n=125)$ (in two groups). To check the efficacy and safety profile, concentration-time curve (AUC) at steady-state and observed maximum steady-state serum concentration $\left(\mathrm{C}_{\max }, \mathrm{ss}\right)$ was evaluated. The approximately same effect was seen in the two groups, as observed in geometric mean AUC for CT-P13 $(32,765.8 \mu \mathrm{gh} / \mathrm{mL})$ and infliximab $(31,359.3 \mu \mathrm{gh} / \mathrm{mL})$. The geometric mean $\mathrm{C}_{\max }$, ss gave almost similar results for infliximab $(144.8 \mu \mathrm{g} / \mathrm{mL})$ and biosimilar $(147.0$ $\mu \mathrm{g} / \mathrm{mL})$. This indicated that CT-P13 is non-inferior option. ${ }^{65}$

In the year 2016, Jahnsen ${ }^{66}$ conducted a study with CT-P13 in IBD patients in South Korea. The study lasted 30 weeks and was conducted on a total of $95 \mathrm{CD}$ and $78 \mathrm{UC}$ patients. Ultimately, $56.1 \%$ and $46.1 \%$ of patients showed clinical remission at the 14 and $30^{\text {th }}$ week, respectively. The investigators concluded that CTP13 is equally effective and well-tolerated as infliximab. ${ }^{66}$ In the same year, Park and colleagues ${ }^{67}$ reported another study's data, after conducting 54 weeks of study on 250 patients, with an interval of 2, 6, 8 up to 54 weeks. In total, 106 and 104 patients were on CT-P13 and infliximab, respectively. Pharmacokinetic (PK) parameters' evaluation showed almost the same serum concentration for both the groups upon the completion of the study; also, minor adverse effects with the same percentage were seen in the patients taking CT-P13 and infliximab. All these results display good tolerability and safety profile of the biosimilar, which motivated to switch to CT-P13 from infliximab. ${ }^{67}$

A data report of IBD study on 210 patients, dividing 126 with $\mathrm{CD}$ and 84 with UC, was submitted by Gecse et al. ${ }^{68}$ in the same year. Data calculated for early clinical remission, response, early biochemical response and steroid-free clinical remission were quite similar between the infliximab and CT-P13 treatments evaluated at week 14 and week 30 . Clinical remission rates at week 14 were more in the $\mathrm{CD}$ patients and the UC patients taking biosimilar as compared to reference. CT-P13 is more effective and safe, as infliximab treatment showed decreased response rates and more allergic reactions. ${ }^{68}$

Further, in 2017, Park and coworkers ${ }^{69}$ extended their study, involving PLANETAS extension. The study was conducted for 102 weeks on the 174 patients who completed 54 weeks of treatment. Maintenance and switch groups included 88 and 86 CT-P13 and infliximab patients, respectively. At the end of 102 weeks, the remission rate, response rate, and minor adverse events were the same. This long-period study was deemed sufficient to justify switching from CT-P13 to infliximab. ${ }^{69}$

Further, in 2017, a study was conducted on 829 candidates, including both $\mathrm{CD}$ and ulcerative colitis patients. Results of the meta-analysis verified that CT-P13 is effective and tolerable. After the administration of CT-P13, the pooled rates of clinical response after $8-14$ weeks were $0.79(95 \%$ confidence interval $(\mathrm{CI})=0.65-0.88)$ and $0.74(95 \% \mathrm{CI}=0.65-0.82)$, among $\mathrm{CD}$ and UC patients, respectively. Rates of sustained clinical response after switching from infliximab to CT-P13 among the CD and UC patients were 0.85 and 0.96 , respectively, at $30-32$ weeks and were 0.75 and 0.83 at $48-63$ weeks, respectively. ${ }^{70}$ Veloz and collaborators $^{71}$ carried out a study with a total of 98 patients with IBD, representing $67 \mathrm{CD}$ and $31 \mathrm{UC}$ patients. In the case of $\mathrm{CD}$, $83.6 \%(56 / 67)$ patients were relieved at the time of the switch and $62.7 \%$ were relieved after 12 months. Similarly, the UC patients showed $80.6 \%(25 / 31)$ remission at the time of the switch and $65.3 \%$ at 12 months. The authors suggested that switching from reference infliximab to CT-P13 does not make significant change. ${ }^{71}$

In another study, 143 IBD patients (involving 99 with CD and 44 with UC) were treated by infliximab and CT-P13. In total, 130 patients continued with the study up to 18 months. After the prolonged period of study, the similarity in disease activity was seen with $2 \%$ adverse effect events. The real-world data of 18 months gave satisfactory results with CT-P13. ${ }^{72}$ Similarly, Ratnakumaran with coworkers ${ }^{73}$ performed a trial, where among 210 IBD patients, 191 were switched to CT-P13 and 19 continued on the infliximab. This pool of patients contains different proportions of fistulizing $\mathrm{CD}$, luminal CD, UC and IBD sufferers. After 12 months, 120 students were in remission. Some adverse effects were seen in those who switched to CT-P13. At the end of the study, no significant difference was seen between remission, response, secondary loss of response, or adverse events between those who switched to CT-P13 and those who stayed on infliximab originator. ${ }^{73}$ In the case of IBD, a trial was conducted on a large pool of patients for 12 months. The evaluation was conducted by symptom-based scores and laboratory markers detected in blood samples. Finally, no significant changes were seen in disease activity in the case of both infliximab and its biosimilar. ${ }^{74}$ Strik et al. ${ }^{75}$ report another study conducted between June 5, 2015 and April 6, 2016 on 120 patients divided almost in the same ratio for UC and CD. Serum level was checked at a specific interval of time, presenting the same level for both reference and CT-P13. Switching to CT-P13 was found to be effective and well-tolerated. ${ }^{75}$

Meyer et $\mathrm{al}^{76}$ reported another study conducted between 1 January 2015 and 30 June 2017 on 3,112 patients (1,434 and 1,678 received reference and CT-P13, respectively). Ultimately, the data collected from 1,453 patients were subjected to multivariate analysis of the primary outcome and demonstrated similar results between CT-P13 and infliximab. The effectiveness of CT-P13 was 
deemed to be the same and side effects were less in UC. ${ }^{76}$ In the same way, Armuzzi and coworkers, ${ }^{77}$ in 2019 , provided another proof with a study on 810 patients, where 754 patients participated in a mean follow-up of $329 \pm 202$ days. At 6 and 12 months, follow-up was completed by 628 (364 CD) and 360 IBD patients (222 CD), respectively. At 12 months, results of the clinical/endoscopic scores and inflammatory biomarkers showed effectiveness and safety of switching to CT-P13. ${ }^{77}$ Tursi and collegues ${ }^{78}$ studied the efficacy and safety of biosimilar infliximab. The reported study was conducted on an IBD out-patient population in IBD centers by Italian regulatory authorities. It was the first large study conducted in IBD centers with follow-up of 24 months. About 141 patients were signed up (96 UC and $45 \mathrm{CD}$ ). The collected data included comprehensive information on sex, age at diagnosis, smoking status, disease extension, disease duration, previous immunosuppressive and anti-TNF- $\alpha$ therapies, concomitant medications at baseline, C-reactive protein (CRP) and fecal calprotectin levels, Mayo score and Mayo subscore for endoscopy for UC patients, and the Harvey-Bradshaw index for CD patients. ${ }^{78}$

Another study involved $308 \mathrm{CD}$ patients and was conducted between August 2014 and February 2017, by Ye et al. ${ }^{79}$ in 2019. A total of 111 students were enrolled for CT-P13 and 109 for infliximab. Both groups showed almost the same results, indicating the non-inferiority of CT-P13 to infliximab. ${ }^{79}$

Recently Ebada et al. ${ }^{80}$ reported a study on a large pool of IBD patients (about 3,464). Thirty-two studies were conducted for CD and UC treated with CT-P13. The response rate at 8-14 weeks were $0.81(95 \% \mathrm{CI}=0.72-0.87)$ and $0.68(95 \% \mathrm{CI}=0.63-0.72)$, and at $48-63$ weeks were $0.69(95 \% \mathrm{CI}=0.48-0.85)$ and 0.54 (95\% CI $=0.45-0.63)$ for $\mathrm{CD}$ and $\mathrm{UC}$, respectively. These rates were found to be $0.84(95 \% \mathrm{CI}=0.57-0.96)$ and $0.96(95 \% \mathrm{CI}$ $=0.58-0.99)$ at $30-32$, and $0.51(95 \% \mathrm{CI}=0.22-0.79)$ and 0.83 $(95 \% \mathrm{CI}=0.19-0.99)$ at $48-63$ weeks for $\mathrm{CD}$ and $\mathrm{UC}$, respectively, after switching from infliximab to CT-P13. Overall, the study shows tolerance of CT-P13 and referral for the treatment of IBD. ${ }^{80}$

In that same year, Bakalos and colleagues ${ }^{81}$ also mentioned the data of the meta-analysis. In 11 studies $(78.6 \%)$, higher rates of biosimilar discontinuation were reported, and in 8 studies, subjective adverse events were reported. ${ }^{81}$

\section{Prospective role of CT-P13 in rheumatoid arthritis}

Rheumatoid arthritis is an autoimmune disease, where the patients mainly suffer from inflamed joints. ${ }^{82}$ Disease occurrence can be seen in all age groups, particularly affecting females as compared to males. According to the data, in the US, 2.1 million adults are suffering from this disease. ${ }^{83}$ The medical and surgical treatment equates to a huge financial loss annually. ${ }^{84}$ Regular trials and studies should be conducted to develop infliximab biosimilars (such as CT-P13), which will control the medical financial conditions of a country. Some data from the trials mentioned in the literature is given below:

In 2012, Yoo et al. ${ }^{85}$ performed a planetary study involving a Phase III randomized, double-blind, multicenter, multinational, parallel-group to evaluate the efficacy and safety of CT-P13 over infliximab for 30 weeks. The 302 and 304 patients were administered CT-P13 and infliximab along with methotrexate and folic acid, respectively. Different parameters and responses were calculated at the end of the study. American College of Rheumatology (ACR) 20 responses were $60.9 \%$ and $58.6 \%$, CRP of $85.8 \%$ and $87.1 \%$, drug-related adverse events of $35.2 \%$ and $35.9 \%$, and anti-drug antibodies of $48.4 \%$ and $48.2 \%$ for CT-P13 and inflixi- mab, respectively. Calculated values are quite comparable, which predicted similarity between safety and efficacy of CT-P13 and infliximab. ${ }^{85}$ In 2015 , Takeuchi and coworkers ${ }^{86}$ reported a 54week study conducted on 104 patients. Among them, 51 patients were taking CT-P13 and 53 patients were taking infliximab along with methotrexate. A total of 3 patients ( 1 in the CT-P13 group and 2 in the infliximab group) departed from the inclusion criteria or matched the exclusion criteria but were included in the safety analysis set. At weeks 6-14, there was no major difference in PK parameters $\left(\mathrm{C}_{\max }, \mathrm{C}_{\mathrm{AV}}, \mathrm{C}_{\min }, \mathrm{PTF}, \mathrm{T}_{\max }, \mathrm{MRT}, \mathrm{T} 1 / 2, \mathrm{CL}\right.$, and $\mathrm{V}_{\mathrm{dss}}$ ) between the CT-P13 and infliximab groups. At the end of the study, similarity in ACR20, ACR50, and ACR70 values was also observed. $^{86}$

In 2016, Yoo with other coworkers, ${ }^{87}$ provided another set of data from a multinational phase III double-blind study, conducted on 606 randomized patients (455 for CT-P13 and 233 for infliximab) up to 54 weeks. At the end of the study, calculated values of ACR20, ACR50 and ACR70 response rates were measured which were found to be quite similar for CT-P13 and infliximab. Measured radiographic progression and antidrug antibodies showed comparable results. ${ }^{87}$

In next year, Yoo et al. ${ }^{88}$ again conducted a study of 102 weeks, where 302 out of 455 patients were selected for the study. The maintenance group containing 158 patients and the switch group containing 144 patients received CT-P13 and infliximab, respectively. The response rate for ACR20, ACR50, ACR70, the proportion of antidrug antibodies and adverse events were similar in both groups. This study stated comparable efficacy and tolerability of CT-P13. ${ }^{88}$

Recently, Anjum and colleagues ${ }^{89}$ conducted a long-standing study of 6 months on 30 patients, involving the variety of arthritis conditions. No major difference was seen in Physician Global Assessment, bath ankylosing spondylitis disease activity index, ankylosing spondylitis disease activity score-CRP, disease activity score (DAS28)-CRP, DAS28- erythrocyte sedimentation rate, CRP, Bechet's disease activity score, and Health Assessment Questionnaire-Disability Index. Retention rates were also comparable between inflectra and remicade; this study confirmed that CT-P13 is a safe and efficacious option. ${ }^{89}$

Rheumatoid arthritis study with various parameter calculations was given by Kim et al. ${ }^{90}$ in 2020 , where DAS28-erythrocyte sedimentation rate, DAS28-CRP and ACR responses were analyzed for 199 rheumatoid arthritis patients with CT-P13 $(n=147)$ and reference infliximab $(n=52)$. However, some changes in treatment were made, where CT-P13 demonstrated improvements over reference infliximab, as seen from the data. From this study, it can be concluded that CT-P13 had a comparable drug retention rate, similar efficacy and acceptable safety profile compared to infliximab. ${ }^{90}$

\section{Prospective role of CT-P13 in psoriatic arthritis}

Psoriasis is an autoimmune skin disease causing itchiness and irritation, sometimes painful. According to the data, 150,000 and 1 million persons are suffering every year in the US and worldwide, respectively. ${ }^{91}$ The regulatory authority approved the anti-TNF- $\alpha$ biosimilars for psoriasis. Change from infliximab to CT-P13 provides a great opportunity for these patients to obtain a similar therapeutic effect with lower prices. ${ }^{92}$ European studies on psoriasis and psoriatic arthritis highlight the positive response for CT-P13 with patient stability. ${ }^{93}$ According to the members of an international psoriasis council, biosimilars should be produced with ap- 
proval and in a standardized, high-quality manner. ${ }^{94}$

In 2016, a study was conducted by Dapavo and colleagues ${ }^{95}$ by dividing patients suffering from plaque psoriasis into two groups. One switched from infliximab to CT-P13 and the other was started with CT-P13. At the end of the induction period, the psoriasis area, severity index and visual analogue pain scale was measured. The results showed that $80 \%$ of patients in group one attained $75 \%$ improvement. Use of CT-P13 with the lesser cost was found to be better, as compared to infliximab. ${ }^{95}$

Further, in 2017, Jørgensen et al. ${ }^{96}$ reported a long-term study conducted on 482 patients, between Oct 24, 2014 and July 8, 2015, dividing patients equally into infliximab and CT-P13 groups, and excluding one person. A total of 408 were included in the per-protocol set. Various disease conditions were included in the study. The percentage of adverse events was almost the same in both groups. The authors claimed that CT-P13 is a non-inferior option over infliximab. ${ }^{96}$

\section{Future directions}

There is a regular increase in the expenditure on very common and dangerous disease conditions and also increment in patient numbers. Due to high cost and limited facility, maximum patients cutback their regular treatment, which leads to high mortality rates. Recently, South Korea and Europe have taken necessary steps towards using the entrituximab biosimilar CT-P10 as an anticancer agent. At present, the US FDA has approved about 26 biosimilars, the latest one being Avsola (a remicade biosimilar). The European Society for Medical Oncology has also suggested that biosimilars are one way to obtain sustainability with optimum prices. Currently, two biosimilars of infliximab are under Phase-III clinical trials and after 5-8 years may enter the market. In the present scenario, the biosimilar concept is not much disclosed but in the near future could become crucial and an avoidable requirement for therapeutics. It could also bring forward a new and interesting era in the field of healthcare for making easy accessibility of all health benefits to patients. Future directions involving long-term clinical trials, re-evaluation of clinical samples for safety, effectiveness, and patient compliance will improve treatment strategies and financial conditions of every country.

\section{Conclusions}

Currently, monoclonal antibodies are continuously replaced by their biosimilars because of their drawbacks. One highly popular example discussed here is infliximab, which has been due to its adverse effects and high cost and which is now being replaced by its biosimilar, CT-P13. CT-P13 resembles the physicochemical and pharmacological profile of infliximab according to its similar mechanism of action, i.e. the anti-TNF- $\alpha$ effect. Along with non-inferiority and better tolerance, it helps to maintain economic conditions of a country. Pharmacists could create awareness among the common people so that they can take the benefit of biosimilar antibodies. However, switching should follow a wellplanned strategy for implementation based on detailed evaluation. This review summarized various comparative studies of using infliximab and its biosimilar CT-P13 conducted on cohorts of patients. Globally, internationally prospective and retrospective studies have confirmed the satisfactory outcomes and enhanced evidences for switching from the original infliximab to its CTP13 biosimilar.

\section{Acknowledgments}

The authors gratefully acknowledge the Management of RayatBahra Institute of Pharmacy, Punjab, Management of School of Medical and Allied Sciences, G. D. Goenka University, Gurugram and Management of Shivalik College of Pharmacy, Nangal, Rupnagar, Punjab for support.

\section{Funding}

No funds of any sort or magnitude were availed from any organization or institute.

\section{Conflict of interest}

The authors have no conflicts of interest related to this publication.

\section{Author contributions}

Compiling the data, designing and writing the manuscript (AK), providing insights into the mechanism of infliximab and infliximab biosimilar (DNP), overall explanation of the pathways (SK), providing guidance at every step of writing and compilation of the manuscript, revising and refining all the literature data provided in the paper (RKS).

\section{References}

[1] Sedger LM, McDermott MF. TNF and TNF-receptors: from mediators of cell death and inflammation to therapeutic giants - past, present and future. Cytokine Growth Factor Rev 2014;25(4):453-472. doi:10.1016/j.cytogfr.2014.07.016.

[2] Kalliolias GD, Ivashkiv LB. TNF biology, pathogenic mechanisms and emerging therapeutic strategies. Nat Rev Rheumatol 2016;12(1):4962. doi:10.1038/nrrheum.2015.169.

[3] Ekert JO, Gould RL, Reynolds G, Howard RJ. TNF alpha inhibitors in Alzheimer's disease: A systematic review. Int J Geriatr Psychiatry 2018;33(5):688-694. doi:10.1002/gps.4871.

[4] Montfort A, Colacios C, Levade T, Andrieu-Abadie N, Meyer N, Ségui B. The TNF paradox in cancer progression and immunotherapy. Front Immunol 2019;10:1818. doi:10.3389/fimmu.2019.01818.

[5] Postal M, Lapa AT, Sinicato NA, de Oliveira Peliçari K, Peres FA, Costallat LT, et al. Depressive symptoms are associated with tumor necrosis factor alpha in systemic lupus erythematosus. J Neuroinflammation 2016;13:5. doi:10.1186/s12974-015-0471-9.

[6] Yost J, Gudjonsson JE. The role of TNF inhibitors in psoriasis therapy: new implications for associated comorbidities. F1000 Med Rep 2009;1:30. doi:10.3410/M1-30.

[7] Ben-Horin S, Kopylov U, Chowers Y. Optimizing anti-TNF treatments in inflammatory bowel disease. Autoimmun Rev 2014;13(1):24-30. doi:10.1016/j.autrev.2013.06.002.

[8] Carswell EA, Old LJ, Kassel RL, Green S, Fiore N, Williamson B. An endotoxin-induced serum factor that causes necrosis of tumors. PNAS 1975;72(9):3666-3670. doi:10.1073/pnas.72.9.3666.

[9] Urschel K, Cicha I. TNF- $\alpha$ in the cardiovascular system: from physiology to therapy. Int J Interferon, Cytokine Mediator Res 2015;7:9-25. doi:10.2147/IJICMR.S64894.

[10] Theiss AL, Simmons JG, Jobin C, Lund PK. Tumor necrosis factor (TNF) alpha increases collagen accumulation and proliferation in intestinal myofibroblasts via TNF receptor 2. J Biol Chem 2005;280(43):3609936109. doi:10.1074/jbc.M505291200. 
[11] Saha RN, Jana M, Pahan K. MAPK p38 regulates transcriptional activity of NF-kappaB in primary human astrocytes via acetylation of p65. J Immunol 2007;179(10):7101-7109. doi:10.4049/jimmunol.179.10.7101.

[12] Wajant H, Siegmund D. TNFR1 and TNFR2 in the control of the life and death balance of macrophages. Front Cell Dev Biol 2019;7:91. doi:10.3389/fcell.2019.00091.

[13] $\mathrm{Hu} W H$, Johnson $H$, Shu HB. Activation of NF-kappaB by FADD, Casper, and caspase-8. J Biol Chem 2000;275(15):10838-10844. doi:10.1074/jbc.275.15.10838.

[14] Ajibade AA, Wang HY, Wang RF. Cell type-specific function of TAK1 in innate immune signaling. Trends Immunol 2013;34(7):307-316. doi:10.1016/j.it.2013.03.007.

[15] Ori D, Kato H, Sanjo H, Tartey S, Mino T, Akira S, et al. Essential roles of K63-linked polyubiquitin-binding proteins TAB2 and TAB3 in B cell activation via MAPKs. J Immunol 2013;190(8):4037-4045. doi:10.4049/ jimmunol.1300173.

[16] Kang YJ, Chen J, Otsuka M, Mols J, Ren S, Wang Y, et al. Macrophage deletion of p38alpha partially impairs lipopolysaccharide-induced cellular activation. J Immunol 2008;180(7):5075-5082. doi:10.4049/ jimmunol.180.7.5075.

[17] Shikama Y, Yamada M, Miyashita T. Caspase-8 and caspase-10 activate NF-kappaB through RIP, NIK and IKKalpha kinases. Eur J Immunol 2003;33(7):1998-2006. doi:10.1002/eji.200324013.

[18] Fleming Y, Armstrong CG, Morrice N, Paterson A, Goedert M, Cohen P. Synergistic activation of stress-activated protein kinase $1 / \mathrm{c}$-Jun $\mathrm{N}$ terminal kinase (SAPK1/JNK) isoforms by mitogen activated protein kinase kinase 4 (MKK4) and MKK7. Biochem J 2000;352:145-154. doi:10.1042/bj3520145.

[19] Baeten D. Infliximab: a chimeric anti-TNF- $\alpha$ monoclonal antibody for the treatment of ankylosing spondylitis and other spondyloarthritides. Therapy 2006;3(2):191-200. doi:10.1586/14750708.3.2.191.

[20] Rau R. Adalimumab (a fully human anti-tumour necrosis factor $\alpha$ monoclonal antibody) in the treatment of active rheumatoid arthritis: the initial results of five trials. Ann Rheum Dis 2002;61(Suppl 2):70-73. doi:10.1136/ard.61.suppl_2.ii70.

[21] Rosa J, Sabelli M, Soriano ER. Prefilled certolizumab pegol (Cimzia ${ }^{\circledR}$ ) syringes for self-use in the treatment of rheumatoid arthritis. Med Devices (Auckl) 2010;3:25-31. doi:10.2147/mder.s7504.

[22] Golimumab (Simponi) a TNF inhibiting monoclonal antibody. Available from: https://emedz.net/golimumab-simponi/. Accessed Mar. 20, 2020.

[23] Downward E. Enbrel ${ }^{\circledR}$ (etanercept) - TNF Inhibitor. Available from: https://ankylosingspondylitis.net/treatment/enbrel/. Accessed Mar. 20, 2020.

[24] NIBSC. First WHO International Standard for Adalimumab now available. Available from: https://www.nibsc.org/about_us/latest_news/ adalimumab standard.aspx. Accessed Mar. 20, 2020.

[25] Joint Formulary Committee. BNF 76 (British National Formulary). 76 edition. Pharmaceutical Press; 2018:1074.

[26] Brooks M. FDA Clears Adalimumab (Humira) for Hidradenitis Suppurativa. Available from: https://www.medscape.com/viewarticle/ 850897. Accessed Feb. 13, 2020.

[27] Sandborn WJ, Feagan BG, Stoinov S, Honiball PJ, Rutgeerts P, Mason $\mathrm{D}$, et al. Certolizumab pegol for the treatment of Crohn's disease. $\mathrm{N}$ Engl J Med 2007;357(3):228-238. doi:10.1056/NEJMoa067594.

[28] Goel N, Stephens S. Certolizumab pegol. mAbs 2010;2(2):137-147. doi:10.4161/mabs.2.2.11271.

[29] Drugs@FDA: FDA-Approved Drugs (Search: Cimzia). Available from: https://www.accessdata.fda.gov/scripts/cder/daf/index.cfm. Accessed Feb. 10, 2020.

[30] FDA. Highlights of prescribing information (CIMZIA $\left.{ }^{\circledR}\right)$. Available from: https://www.accessdata.fda.gov/drugsatfda_docs/label/2016/ 125160s241lbl.pdf. Accessed Mar. 20, 2020.

[31] Biosimilars of certolizumab pegol. Available from: http://www.gabionline.net/Biosimilars/General/Biosimilars-of-certolizumab-pegol. Accessed Mar. 20, 2020

[32] Mazumdar S, Greenwald D. Golimumab. mAbs 2009;1(5):422-431. doi:10.4161/mabs.1.5.9286.

[33] Bio-Thera Solutions Initiates Phase I Clinical Trial for BAT2506, a Proposed Biosimilar of Simponi ${ }^{\circledR}$ (Golimumab). Available from: https://
www.businesswire.com/news/home/20190814005245/en/BioThera-Solutions-Initiates\%20Phase-Clinical-Trial-BAT2506. Accessed Dec. 12, 2019.

[34] Infliximab. Available from: https://www.pharmacodia.com/yaodu/ html/v1/biologics/c19af480c40e343bbac3e2c01967b09f.html. Accessed Mar. 20, 2020.

[35] Mitoma H, Horiuchi T, Tsukamoto H, Ueda N. Molecular mechanisms of action of anti-TNF- $\alpha$ agents- Comparison among therapeutic TNF- $\alpha$ antagonists. Cytokine 2018;101:56-63. doi:10.1016/j. cyto.2016.08.014.

[36] Lerch TF, Sharpe P, Mayclin SJ, Edwards TE, Lee E, Conlon HD, et al. Infliximab crystal structures reveal insights into self-association. mAbs 2017;9(5):874-883. doi:10.1080/19420862.2017.1320463.

[37] White C. Infliximab biosimilars are safe, effective, and cheap, UK audit shows. BMJ 2016;354:i5084. doi:10.1136/bmj.i5084.

[38] Specialist Inflammatory Bowel Disease service created. Available from: https://www.hdft.nhs.uk/news/ibdservice/. Accessed Mar. 20, 2020.

[39] Declerck P, Danesi R, Petersel D, Jacobs I. The language of biosimilars: clarification, definitions, and regulatory aspects. Drugs 2017;77(6):671-677. doi:10.1007/s40265-017-0717-1.

[40] Biosimilar Development, Review, and Approval. Available from: https://www.fda.gov/drugs/biosimilars/biosimilar-development review-and-approval. Accessed Jan. 28, 2020.

[41] FDA antibody biosimilar product approvals increase in 2019. Available from: https://www.europeanpharmaceuticalreview.com/news/ 96493/fda-antibody-biosimilar-product-approvals-increasein-2019/. Accessed Jan. 2, 2020.

[42] Ranbaxy Launches India's First Biosimilar of Infliximab Drug, Infimab. Available from: http://www.fwbiosimilars.com/ranbaxy-launchesindia\%E2\%80\%99s-first-biosimilar-infliximab-drug-infimab. Accessed Dec. 20, 2019.

[43] Yoo DH, Jaworski J, Matyska-Piekarska E, Smiyan S, Ivanova D, Zielinska A, et al. FRI0128 a novel formulation of CT-P13 (infliximab biosimilar) for subcutaneous administration: 1 -year results from a part 1 of phase I/III randomized controlled trial in patients with active rheumatoid arthritis. Annals of the Rheumatic Diseases 2019;78:733. doi:10.1136/annrheumdis-2019-eular.1094.

[44] Safety of SC form of infliximab biosimilar CT-P13. Available from: http://www.gabionline.net/Biosimilars/Research/Safety-of-SC-formof-infliximab-biosimilar-CT-P13. Accessed Dec. 24, 2019.

[45] Severs M, Oldenburg B, van Bodegraven AA, Siersema PD, Mangen MJ. The economic impact of the introduction of biosimilars in inflammatory bowel disease. J Crohns Colitis 2017;11(3):289-296. doi:10.1093/ecco-jcc/jjw153.

[46] Rencz F, Péntek M, Bortlik M, Zagorowicz E, Hlavaty T, Śliwczyński A, et al. Biological therapy in inflammatory bowel diseases: access in Central and Eastern Europe. World J Gastroenterol 2015;21(6):17281737. doi:10.3748/wjg.v21.i6.1728.

[47] European Medicines Agency, European Commission. Biosimilars in the EU, information guide for healthcare professionals. Available from: https://www.ema.europa.eu/en/documents/leaflet/biosimilars-eu-information-guide-healthcare-professionals_en.pdf. Accessed Mar. 20, 2019.

[48] World Health Organization. Guidelines on evaluation of similar biotherapeutic products (SBPs). Available from: https://www.who.int/ biologicals/areas/biological therapeutics/BIOTHERAPEUTICS FOR WEB_22APRIL2010.pdf. Accessed Jan. 6, 2020.

[49] WHO Expert Committee on Biological Standardization. Annex 2: Guidelines on evaluation of similar biotherapeutic products (SBPs). Available from: https://www.who.int/biologicals/publications/trs/ areas/biological therapeutics/TRS_977_Annex_2.pdf?ua=1. Accessed Feb. 9, $20 \overline{2} 0$.

[50] Alliance for Safe Biologic Medicines. Non-Medical Switching (NMS). Available from: https://safebiologics.org/non-medical-switching/. Accessed Mar. 12, 2020.

[51] Bernard EJ, Fedorak RN, Jairath V. Systematic Review: Non-medical Switching of Infliximab to CT-P13 in Inflammatory Bowel Disease. Dig Dis Sci 2020. doi:10.1007/s10620-019-06036-0.

[52] Evaluate ${ }^{\mathrm{TM}}$. KFDA approves Remsima (infliximab), the world's first antibody biosimilar. Available from: http://www.evaluategroup.com/ 
Universal/View.aspx?type=Story\&id=320129. Accessed Dec. 1, 2019.

[53] European Medicines Agency. Guideline on similar biological medicinal products containing monoclonal antibodies - non-clinical and clinical issues. Available from: https://www.ema.europa.eu/en/ documents/scientific-guideline/guideline-similar-biological-medicinal-products-containing-monoclonal-antibodies-non-clinical_en.pdf. Accessed Jan. 27, 2020.

[54] Extrapolation of indications for biosimilar infliximab and etanercept. Available from: http://gabionline.net/Biosimilars/Research/Extrapolation-of-indications-for-biosimilar-infliximab-and-etanercept. Accessed Mar. 20, 2020.

[55] Guideline on good pharmacovigilance practices (GVP). Available from: https://www.ema.europa.eu/en/documents/scientific-guideline/guideline-good-pharmacovigilance-practices-module-v-riskmanagement-systems-rev-2_en.pdf. Accessed Mar. 20, 2020.

[56] Elflein J. Inflammatory bowel disease in the U.S. - Statistics \& Facts (2019 September). Available from: https://www.statista.com/topics/4340/inflammatory-bowel-disease-ibd-in-the-us/. Accessed Jan. 19, 2020.

[57] InflammatoryBowelDisease.net. Statistics. Available from: https:// inflammatoryboweldisease.net/what-is-crohns-disease/statistics/. Accessed Jan. 29, 2020.

[58] Razanskaite V, Bettey M, Downey L, Wright J, Callaghan J, Rush M, et al. Biosimilar infliximab in inflammatory bowel disease: outcomes of a managed switching programme. J Crohns Colitis 2017;11(6):690696. doi:10.1093/ecco-jcc/jjw216.

[59] Gisbert JP, Chaparro M. Switching from an originator anti-TNF to a biosimilar in patients with inflammatory bowel disease: Can it be recommended? A systematic review. Gastroenterol Hepatol 2018;41(6):389-405. doi:10.1016/j.gastrohep.2018.04.005

[60] Kelly JC. Biosimilar CT-P13 Matches Infliximab for Crohn's Disease. Available from: https://www.medscape.com/viewarticle/906439. Accessed Jan. 11, 2020.

[61] Buer LC, Moum BA, Cvancarova M, Warren DJ, Medhus AW, Høivik ML. Switching from Remicade ${ }^{\circledR}$ to Remsima ${ }^{\circledR}$ is well Tolerated and Feasible: A Prospective, Open-label Study. J Crohns Colitis 2017;11(3):297-304. doi:10.1093/ecco-jcc/jjw166.

[62] Gecse KB, D'Haens GR. Infliximab biosimilar CT-P13 in Crohn's disease. Lancet 2019;393(10182):1671-1672. doi:10.1016/S01406736(18)32778-8.

[63] Gheorghe C, Svoboda P, Mateescu B. Effectiveness and safety of biosimilar infliximab (CT-P13) in a real-life setting in patients with Crohn's disease or ulcerative colitis. J Drug Assess 2019;8(1):129134. doi:10.1080/21556660.2019.1626735.

[64] Mezones-Holguin E, Gamboa-Cardenas RV, Sanchez-Felix G, ChávezCorrales J, Helguero-Santin LM, Laban Seminario LM, et al. Efficacy and safety in the continued treatment with a biosimilar drug in patients receiving infliximab: a systematic review in the context of decision-making from a latin-American country. Front Pharmacol 2019;10:1010. doi:10.3389/fphar.2019.01010.

[65] Park W, Hrycaj P, Jeka S, Kovalenko V, Lysenko G, Miranda P, et al. A randomised, double-blind, multicentre, parallel-group, prospective study comparing the pharmacokinetics, safety, and efficacy of CT-P13 and innovator infliximab in patients with ankylosing spondylitis: the PLANETAS study. Ann Rheum Dis 2013;72(10):1605-1612. doi:10.1136/annrheumdis-2012-203091.

[66] Jahnsen J. Clinical experience with infliximab biosimilar Remsima (CT-P13) in inflammatory bowel disease patients. Therap Adv Gastroenterol 2016;9(3):322-329. doi:10.1177/1756283X16636764.

[67] Park W, Yoo DH, Jaworski J, Brzezicki J, Gnylorybov A, Kadinov V, et al. Comparable long-term efficacy, as assessed by patient-reported outcomes, safety and pharmacokinetics, of CT-P13 and reference infliximab in patients with ankylosing spondylitis: 54-week results from the randomized, parallel-group PLANETAS study. Arthritis Res Ther 2016;18:25. doi:10.1186/s13075-016-0930-4.

[68] Gecse KB, Lovász BD, Farkas K, Banai J, Bene L, Gasztonyi B, et al. Efficacy and safety of the biosimilar infliximab CT-P13 treatment in inflammatory bowel diseases: a prospective, multicentre, nationwide cohort. J Crohns Colitis 2016;10(2):133-140. doi:10.1093/ecco-jcc/ jjv220.

[69] Park W, Yoo DH, Miranda P, Brzosko M, Wiland P, Gutierrez-Ureña S, et al. Efficacy and Safety of Switching from Reference Infliximab to CTP13 Compared With Maintenance of CT-P13 in Ankylosing Spondylitis: 102-week Data From the PLANETAS Extension Study. Ann Rheum Dis 2017;76(2):346-354. doi:10.1136/annrheumdis-2015-208783.

[70] Komaki Y, Yamada A, Komaki F, Micic D, Ido A, Sakuraba A. Systematic review with meta-analysis: the efficacy and safety of CT-P13, a biosimilar of anti-tumour necrosis factor- $\alpha$ agent (infliximab), in inflammatory bowel diseases. Aliment Pharmacol Ther 2017;45(8):10431057. doi:10.1111/apt.13990.

[71] Guerra Veloz MF, Vázquez Morón JM, Belvis Jiménez M, Pallarés Manrique $\mathrm{H}$, Valdés Delgado $\mathrm{T}$, Castro Laria L, et al. Switching from reference infliximab to in patients with inflammatory bowel disease: results of a multicenter study after 12 months. Rev Esp Enferm Dig 2018;110(9):564-570. doi:10.17235/reed.2018.5368/2017.

[72] Høivik ML, Buer LCT, Cvancarova M, Warren DJ, Bolstad N, Moum BA, et al. Switching from originator to biosimilar infliximab-real world data of a prospective 18 months follow-up of a single-centre IBD population. Scand J Gastroenterol 2018;53(6):692-699. doi:10.1080 /00365521.2018.1463391.

[73] Ratnakumaran R, To N, Gracie DJ, Selinger CP, O’Connor A, Clark T, et al. Efficacy and tolerability of initiating, or switching to, infliximab biosimilar CT-P13 in inflammatory bowel disease (IBD): a large singlecentre experience. Scand J Gastroenterol 2018;53(6):700-707. doi:1 0.1080/00365521.2018.1464203.

[74] Bergqvist V, Kadivar M, Molin D, Angelison L, Hammarlund P, Olin M, et al. Switching from originator infliximab to the biosimilar CT-P13 in 313 patients with inflammatory bowel disease. Therap Adv Gastroenterol 2018;11:1756284818801244. doi:10.1177/1756284818801244.

[75] Strik AS, van de Vrie W, Bloemsaat-Minekus JPJ, Nurmohamed M, Bossuyt PJJ, Bodelier A, et al. Serum concentrations after switching from originator infliximab to the biosimilar CT-P13 in patients with quiescent inflammatory bowel disease (SECURE): an open-label, multicentre, phase 4 non-inferiority trial. Lancet Gastroenterol Hepatol 2018;3(6):404-412. doi:10.1016/S2468-1253(18)30082-7.

[76] Meyer A, Rudant J, Drouin J, Coste J, Carbonnel F, Weill A. The effectiveness and safety of infliximab compared with biosimilar CT$\mathrm{P} 13$, in 3112 patients with ulcerative colitis. Aliment Pharmacol Ther 2019;50(3):269-277. doi:10.1111/apt.15323.

[77] Armuzzi A, Fiorino G, Variola A, Manetti N, Fries W, Orlando A, et al. The PROSIT cohort of infliximab biosimilar in IBD: A prolonged follow-up on the effectiveness and safety across Italy. Inflamm Bowel Dis 2019;25(3):568-579. doi:10.1093/ibd/izy264.

[78] Tursi A, Mocci G, Faggiani R, Allegretta L, Valle ND, Forti G, et al. Infliximab biosimilar CT-P13 is effective and safe in treating inflammatory bowel diseases: a real-life multicenter, observational study in Italian primary inflammatory bowel disease centers. Ann Gastroenterol 2019;32(4):392-399. doi:10.20524/aog.2019.0377.

[79] Ye BD, Pesegova M, Alexeeva O, Osipenko M, Lahat A, Dorofeyev A, et al. Efficacy and safety of biosimilar CT-P13 compared with originator infliximab in patients with active Crohn's disease: an international, randomised, double-blind, phase 3 non-inferiority study. Lancet 2019;393(10182):1699-1707. doi:10.1016/S0140-6736(18)32196-2.

[80] Ebada MA, Elmatboly AM, Ali AS, Ibrahim AM, Fayed N, Faisal AF, et al. An updated systematic review and meta-analysis about the safety and efficacy of infliximab biosimilar, CT-P13, for patients with inflammatory bowel disease. Int J Colorectal Dis 2019;34(10):1633-1652. doi:10.1007/s00384-019-03354-7.

[81] Bakalos G, Zintzaras E. Drug discontinuation in studies including a switch from an originator to a biosimilar monoclonal antibody: a systematic literature review. Clin Ther 2019;41(1):155-173.e13. doi:10.1016/j.clinthera.2018.11.002.

[82] Healthline. Rheumatoid Arthritis by the Numbers: Facts, Statistics, and You. Available from: https://www.healthline.com/health/rheumatoid-arthritis/facts-statistics-infographic. Accessed Jan 19, 2020.

[83] AmeriPharma Specialty Care. An Overview of Rheumatoid Arthritis. Available from: https://ameripharmaspecialty.com/an-overview-ofrheumatoid-arthritis/. Accessed Feb. 9, 2020.

[84] eMedTV. Rheumatoid Arthritis Statistics. Available from: http://arthritis.emedtv.com/rheumatoid-arthritis/rheumatoid-arthritis-statistics.html. Accessed Jan. 12, 2020.

[85] Yoo DH, Hrycaj P, Miranda P, Ramiterre E, Piotrowski M, Shevchuk 
$\mathrm{S}$, et al. A randomised, double-blind, parallel-group study to demonstrate equivalence in efficacy and safety of CT-P13 compared with innovator infliximab when coadministered with methotrexate in patients with active rheumatoid arthritis: the PLANETRA study. Ann Rheum Dis 2013;72(10):1613-1620. doi:10.1136/annrheumdis-2012-203090.

[86] Takeuchi T, Yamanaka H, Tanaka Y, Sakurai T, Saito K, Ohtsubo H, et al. Evaluation of the pharmacokinetic equivalence and 54-week efficacy and safety of CT-P13 and innovator infliximab in Japanese patients with rheumatoid arthritis. Mod Rheumatol 2015;25(6):817-824. doi :10.3109/14397595.2015.1022297.

[87] Yoo DH, Racewicz A, Brzezicki J, Yatsyshyn R, Arteaga ET, Baranauskaite $A$, et al. A phase III randomized study to evaluate the efficacy and safety of CT-P13 compared with reference infliximab in patients with active rheumatoid arthritis: 54-week results from the PLANETRA study. Arthritis Res Ther 2016;18:82. doi:10.1186/s13075-016-0981-6.

[88] Yoo DH, Prodanovic N, Jaworski J, Miranda P, Ramiterre E, Lanzon A, et al. Efficacy and safety of CT-P13 (biosimilar infliximab) in patients with rheumatoid arthritis: comparison between switching from reference infliximab to CT-P13 and continuing CT-P13 in the PLANETRA extension study. Ann Rheum Dis 2017;76(2):355-363. doi:10.1136/ annrheumdis-2015-208786.

[89] Aqeel M Anjum, Ng WL, Sebastian A, Devlin J, Fraser A. Real life switching from infliximab innovator to biosimilar in rheumatic diseases: a 6-month single-centre prospective observational study. Fortune J Rheumatol 2019;1:40-49. doi:10.26502/fjr.26880011.

[90] Kim HA, Lee E, Lee SK, Park YB, Lee YN, Kang HJ, et al. Retention rate and safety of biosimilar CT-P13 in rheumatoid arthritis: data from the Korean college of rheumatology biologics registry. BioDrugs 2020;34(1):89-98. doi:10.1007/s40259-019-00393-y.

[91] Healthline. Psoriasis: Facts, Statistics, and You. Available from: https://www.healthline.com/health/psoriasis/facts-statistics-infographic\#2. Accessed Jan. 19, 2020.

[92] Barker J, Girolomoni G, Egeberg A, Goncalves J, Pieper B, Kang T. AntiTNF biosimilars in psoriasis: from scientific evidence to real-world experience. J Dermatolog Treat 2019. doi:10.1080/09546634.2019.161 0553.

[93] Kurizky PS, Galvão LO, Martins GA. Efficacy and safety of biosimilar infliximab CT-P13 in the treatment of psoriasis and psoriatic arthritis: 1-year follow-up. An Bras Dermatol 2019;94(4):483-484. doi:10.1590/abd1806-4841.20198358.

[94] Blauvelt A, Cohen AD, Puig L, Vender R, van der Walt J, Wu JJ. Biosimilars for psoriasis: preclinical analytical assessment to determine similarity. Br J Dermatol 2016;174(2):282-286. doi:10.1111/bjd.14267.

[95] Dapavo P, Vujic I, Fierro MT, Quaglino P, Sanlorenzo M. The infliximab biosimilar in the treatment of moderate to severe plaque psoriasis. J Am Acad Dermatol 2016;75(4):736-739. doi:10.1016/j. jaad.2016.04.068.

[96] Jørgensen KK, Olsen IC, Goll GL, Lorentzen M, Bolstad N, Haavardsholm EA, et al. Switching from originator infliximab to biosimilar CT-P13 compared with maintained treatment with originator infliximab (nor-switch): a 52-week, randomised, double-blind, non-inferiority trial. Lancet 2017;389(10086):2304-2316. doi:10.1016/S0140 6736(17)30068-5. 